\title{
Neutrophil defensin activates mitogen-activated protein kinase and activator protein-I to induce interleukin-8 release from airway epithelial cells
}

\begin{abstract}
Background: Neutrophils sequestrated in the lung and release of proinflammatory mediators, including neutrophil defensin are responsible for sepsis-induced micro vascular permeability and alveolar epithelial cell damage.

Objective: To investigate whether Neutrophil defensin might indirectly contribute to lung injury through their capacity to induce synthesis of IL-8 in epithelial cells, A549 epithelial cells were incubated with Neutrophil defensin (human neutrophil peptide; 1 , 5 and $10 \mathrm{mg} / \mathrm{ml}$ ) for 30 minutes, 2 hours and 6hours
\end{abstract}

Methods: The IL-8 was analyzed by ELISA or by RT-PCR to measure IL-8 synthesis capacity. The mitogen-activated protein kinase (MAPK) activities were detected by western blot analysis

Results: Neutrophil defensin dose-dependently increased IL-8 release from cultured A549 epithelial cells. The MAPK, ERK, was up regulated by Neutrophil-defensin. Activator protein-1 (AP-1) but not nuclear transcriptional factor-kappa B (NF-kB) was also activated. Specific inhibitors of ERK inhibitor, PD 98059, but not NF-kB inhibitor, PDTC, significantly inhibited defensin-induced IL-8 release and mRNA expression. The specific tyrosine kinase (TK) inhibitor, genistein, or protein kinase $\mathrm{C}$ (PKC) inhibitor, Go 6976 also inhibited IL-8 release and mRNA expression.

Conclusion: Our results indicate neutrophil defensin activates ERK through AP-1 to up regulate IL- 8 mRNA expression and protein synthesis. Tyrosine kinase (TK) and $\mathrm{PKC}$ are implicated in neutrophil-defensin activation of MAPK pathway.

Keywords: mitogen-activated protein kinase, activator protein-1, defensin, Il-8
Volume I Issue 3 - 2014

\author{
Horng-Chyuan Lin, Meng-Heng Hsieh, Yueh- \\ Fu Fang, Fu-Tsai Chung \\ Department of Thoracic Medicine, Chang Gung University, \\ Taiwan
}

Correspondence: Horng-Chyuan Lin, Department of Thoracic Medicine, Chang Gung Medical Foundation, Chang Gung University College of Medicine, Taoyuan, Taiwan, Tel +886-33281200 , ext 8467, Fax +886-3-3287787, Email lin53424@ms I3.hinet.net

Received:September 22, 20I4 | Published: October 0I, 2014
Abbreviations: MAPK, mitogen-activated protein kinase; ERK, extracellular signal-regulated kinase; AP-1, activator protein-1; NF- $\mathrm{BB}$, nuclear transcriptional factor- kappa B; IL-8, interleukin-8; $\mathrm{PKC}$, protein kinase $\mathrm{C}$

\section{Introduction}

Tissue injury in various inflammatory lung diseases is associated with local neutrophil accumulation. Recruitment or sequestration of neutrophils significantly increases the inflammatory burden, which is exaggerated during pulmonary infection. ${ }^{1}$ The large numbers of neutrophils place the airspace in great jeopardy consequent to the exposure to potent neutrophil mediators, including neutrophil defensin, elastase, reactive oxygen species, and a variety of cytokines. ${ }^{1,2}$

To reach lung interstitium, neutrophils within the pulmonary vasculature must adhere to and subsequently migrate through endothelium. Similarly, to reach the alveolar space or airway lumen, neutrophils must transmigrate through pulmonary or airway epithelium. Adherence and chemotaxis are thought to be primordial mechanisms by which neutrophils can function either in host defence or tissue injury. ${ }^{1,3}$ A variety of proinflammatory mediators, such as IL-8, IL-6, (RANTES), and (TNF)- $\alpha$ are elaborated from airway or alveolar epithelial cells. ${ }^{4,5}$ Among them, IL-8 plays a critical role in recruitment of neutrophils to epithelial cells. IL-8 is produced from epithelial cells constitutively in low amount and in large amounts in response to IL- 1 and TNF- $\alpha$ stimulation. ${ }^{6}$
Recently, it was shown that neutrophil-derived defensins, elastase, proteinase 3, and induced IL-8 synthesis in lung epithelial cells. ${ }^{7}$ Defensins, or human neutrophil peptides, are cationic proteins with antimicrobial activity against bacteria, fungi and certain enveloped viruses. They are the major constituents of the azurophilic granules of neutrophils, and represent $5-7 \%$ of the total cellular protein in human neutrophils. Defensins released by stimulated neutrophils may contribute to the local chemokine network, especially IL-8, at sites of neutrophil-dominated inflammation in the airways, resulting in an additional influx of inflammatory cells. The release these granule proteins from stimulated neutrophils at mucosal surfaces may increase the recruitment of additional neutrophils to the site of inflammation. Though the injurious effects of stimulated neutrophils in vitro are well documented, the responsible intracellular regulatory mechanism is not yet delineated.

The mitogen-activated protein kinases (MAPK) are important mediators of signal transduction from the cell membrane to the nucleus. Several subgroups of mammalian MAPKs have been molecularly characterized, including extracellular signal-regulated kinase (ERK), c-Jun NH2-terminal kinase (JNK), and p38 MAPK. ${ }^{8}$ The p38 MAPK, which is a mammalian homologue of the HOG-1 of the High osmolarity glycerol (HOG)-1 Saccharomyces cerevisiae, ${ }^{9}$ is activated in various cells by proinflammatory cytokines, environmental stresses, (DNA)-damaging agents, and hematopoietic growth factor. ${ }^{10,11}$ P38 MAPK has been demonstrated to play an important role in the release 
and gene expression of IL- 8 in response to the stimulation by TNF- $\alpha$, IL-1 $\alpha$, and platelet-activating factor (PAF) on bronchial epithelial cells ${ }^{12}$ or LPS on monocytes ${ }^{13}$ or Salmonella typhimurium on cultured intestinal epithelial cells. ${ }^{14}$ Other MAPKs, such as ERK was also reported to be necessary for cytokine gene transcription. ${ }^{15}$ However, none is known about the role of p38 MAPK or other subgroups of MAPK in neutrophil defense induced proinflammatory cytokine expression in alveolar epithelial cells.

The promoter of the gene encoding IL-8 contains sequences for binding several nuclear transcription factors (NF), including NF$\kappa \mathrm{B}$ and activator protein-1 (AP-1). ${ }^{14,16,17}$ These transcription factors participate to various extents in the inducible expression of the genes encoding IL-8. The p38 mitogen-activated protein (MAP) kinase has been implicated in the activation of multiple transcription factors, including NF- $\mathrm{\kappa B}, \mathrm{CHOP}$, and activating transcription factor (ATF)$2{ }^{10,18,19}$ In this study the relationship between MAPK activation and the expression of transcription factors that involves neutrophil defensin-induced IL-8 synthesis was investigated.

\section{Materials and methods}

\section{Epithelial cell cultures}

A549 type II-like lung epithelial cells were cultured as previously described. $^{20,21}$ Confluent mono layers of culture were used for experiments. A549 cells were stimulated with human neutrophil defensin $(1-10 \mu \mathrm{g} / \mathrm{ml})$ and incubated with or without specific inhibitors of MAPK, NF- $\mathrm{kB}$, tyrosin kinase, and protein kinase $\mathrm{C}^{22} 1 \mathrm{~h}$ before defensin. The cell viability was determined by trypan blue staining.

\section{Measurement of IL-8}

The concentration of IL- 8 in the culture supernatants from A549 cells were measured by commercially available ELISA kits (R\&D Systems Inc. Minneapolis, USA). ${ }^{21}$ ELISA was performed according to the manufacturer's instruction. All samples were assayed in duplicate.

\section{Cell extracts preparation and western blot analysis}

After experiments, 5x106 cultured A549 cells were washed, then lysed with ice-cold cytoplasmic extraction buffer with protease inhibitors (Roche Molecular Biochemicals) as described previously. ${ }^{23}$ After separating proteins from cell lysate by polyacrylamide gel electrophoresis, proteins were transferred to a nitrocellulose membrane. The membranes were then incubated with TTBS containing $0.1 \%$ non fat milk, and then with specific antibodies for AP-1, NF- $\mathrm{kB}$, phosphorylated or non-phosphorylated MAPKs, and then with horse-radish peroxidase-conjugated anti-rabbit antibody. The resulting gel was dried and autoradiographed. The bands were quantitated using a densitometer with Image Quant software.

\section{Western blot analysis of transcription factors}

Cytoplasmic extracts were thawed and subjected to sodium dodecyl sulfate polyacrylamide gel electrophoresis (SDS-PAGE) and blotted onto nitrocellulose. AP-1 was detected using a mouse anti-human AP-1 anti body (Transduction Lab.) and detected using alkaline phosphatase-conjugated anti-mouse antibody. NF- $\mathrm{kB}$ was detected using a mouse anti-human NF- $\mathrm{kB}$ antibody (Transduction Lab.) and detected using alkaline phosphatase-conjugated anti-mouse antibody. Blots were developed by adding of BCIP/NBT [5-bromo4-chloro-3-indolyl-phosphate (BCIP) with nitro blue tetrazolium
(NBT)] solution (Sigma), and then exposed to XAR films (Eastman Kodak, Rochester, NY).

\section{Western blot analysis of MAP kinase}

The tyrosine phosphorylation of p38 MAP kinase and ERK kinase were analyzed by commercially available kits (New England Biolabs. Inc. Beverly, Mass.). Analysis of tyrosine phosphorylation of p38 MAP kinase and ERK kinase were performed according to the manufacturer's instruction. Briefly, the cells that have been washed with cold Tris-buffered saline were lysed in sodium dodecylsulfate (SDS) buffer $(62.5 \mathrm{mmol} / \mathrm{L}$ Tris- $\mathrm{HCl}$ [pH 6.8], 2\% wt/vol SDS, $10 \%$ glycerol, $50 \mathrm{mmol} / \mathrm{L}$ dithiothreitol, and $0.1 \% \mathrm{wt} / \mathrm{vol}$ bromphenol blue) for $15 \mathrm{~min}$ on ice and sonicated for 2 seconds to shear DNA. The samples were heated in a boiling water bath for $5 \mathrm{~min}$ to fully denature the proteins before electrophoresis and then centrifuged at $12,000 \mathrm{~g}$ for $5 \mathrm{~min}$ to remove insoluble debris. After separating proteins from cell lysate by $15 \%$ sodium dodecyl sulfate-polyacrylamide gel electrophoresis, proteins were electrophoretically transferred to a nitrocellulose membrane, and the membranes was washed with $0.1 \%$ Tween-20 supplemented with Tris-buffered saline (washing buffer). To block nonspecific protein binding, the membrane was incubated with $0.1 \%$ Tween-20 supplemented with Tris-buffered saline containing $5 \% \mathrm{wt} / \mathrm{vol}$ non fat dry milk for 3 hours at room temperature. It was then incubated with specific antibody to phosphorylated tyrosine of p38 MAP kinase or ERK kinase (affinity-purified rabbit polyclonal $\mathrm{IgG}$ ) at $1: 1000$ dilution in $0.1 \%$ Tween-20 supplemented with Tris-buffered saline containing $5 \%$ bovine serum albumin at $4 \mathrm{oC}$ overnight with gentle shaking. After washing with washing buffer three times, it was incubated for 1 hour with gentle shaking at room temperature with the horse-radish peroxidase-conjugated anti-rabbit antibody (1:2000) and horseradish peroxidase-conjugated anti-biotin antibody $(1: 1000)$ to detect biotinylated protein markers. It was then washed three times with washing buffer. Blots were incubated with enhanced chemiluminescence solution (LumiGLO) for $1 \mathrm{~min}$ at room temperature and exposed on KODAK XAR film. To show the amounts of $\mathrm{p} 38$ or ERK MAP kinase precipitated blots were stripped and reprobed with phosphorylation state-independent p38 or ERK MAP kinase-specific antibody to determine total p38 or ERK MAP kinase levels (affinity-purified rabbit polyclonal IgG).

\section{Reverse transcriptase-polymerase chain reaction (RT- PCR)}

Total RNA was extracted using the guanidine thiocyanate/phenol/ chloroform method described previously. ${ }^{24}$ Five mg of RNA was reversed transcribed using oligo (dT) 12-18 primers. The cDNA was amplified by PCR using specific primers (GIBCO-BRL) for IL-8. The reverse-transcribed cDNA was added with specific IL-8 primer pairs to a PCR mix with $1 \mathrm{U}$ of Tag DNA polymerase $(0.5 \mu \mathrm{g} / 2 \mu \mathrm{l})$. After 25 cycles, the PCR products were run on a $2 \%$ agarose gel. The gel was stained with ethidium bromide, photographed, and the bands quantitated by densitometer scan. Each gel was run with GAPDH, a housekeeping gene for comparison of expression. All PCR primers were synthesized by GIBCO-BRL.

\section{Terminal Deoxynucleotidyl transferase-mediated fluorescein-dutp nick end-labeling (Tunel) staining}

Defensin stimulated epithelial cells undergoing apoptosis were identified by means of the TdT-mediated dUTP-dioxigenin nick-end labeling (TUNEL) method, which specifically labels the 3'-hydroxyl 
terminal of DNA strand breaks. For the TUNEL procedure, all agents, including buffers, were part of a kit (apoptosis in situ detection kit; Wako Pure Chemical Co.); the staining procedure was carried out according to the manufacturer's recommendation. Negative controls include omission of TdT. Positive controls included treatment of the samples with Dnase I. Apoptotic cells were recognized by their dark nuclear staining (TUNEL-positive), and nuclei of nonapoptotice cells were visualized by staining with methyl green.

\section{Statistics}

All data were expressed as mean + standard error of mean (SEM). One-way analysis of variance (ANOVA) for mixed design was used to compare values of more than two different experimental groups. The data were analyzed by Student's t-test between groups.

\section{Results}

\section{Defensin induced IL-8 release}

A549 epithelial cells were incubated with neutrophil defensin (human neutrophil peptide; 1,5 and $10 \mu \mathrm{g} / \mathrm{ml}$ ) for 30 minutes, 2 hours and 6hours. Stimulation of A549 epithelial cells with human neutrophil defensin for 6hours dose-dependently induced IL-8 release (Figure 1). Defensin significantly induced IL-8 release from A549 cells at $5(390.8+9.5 \mathrm{pg} / \mathrm{ml})$ and $10 \mu \mathrm{g} / \mathrm{ml}(485.8+12.7 \mathrm{pg} / \mathrm{ml})$ after $6 \mathrm{~h}$ incubation, compared with control $(189.4+4.0 \mathrm{pg} / \mathrm{ml}, \mathrm{n}=10, \mathrm{p}<0.0001$ respectively).

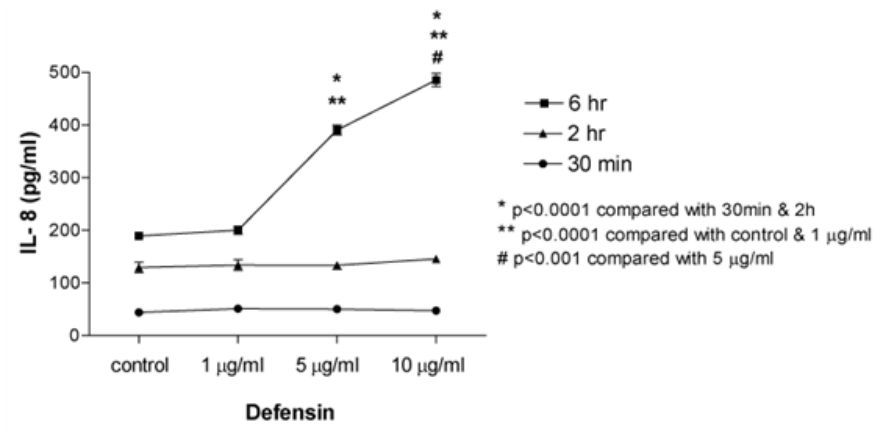

Figure I Effect of human neutrophil defensin (human neutrophil peptide; I, 5 and $10 \mu \mathrm{g} / \mathrm{ml})$ on IL-8 release from cultured A549 epithelial cells. Data are mean+SEM.

\section{Defensin induced MAPK activation}

A549 epithelial cells were stimulated with defensin $(10 \mu \mathrm{g} / \mathrm{ml})$ for desired time as indicated in order to determine the time-course activation of MAPKs induced by defensin. Neutrophil-defensin increased ERK1/ERK2 activation in the cytoplasmic extract of defensin-stimulated A549 cells, and reached the maximum at 10min, and returned to basal level thereafter. There was no significant change in p38 MAPK and JNK activation (Figure 2). The ERK1/ERK2 activation occurred after $5 \mu \mathrm{g} / \mathrm{ml}$ defensin stimulation, and reached the maximum at $10 \mu \mathrm{g} / \mathrm{ml}$ (Figure 3 ).

\section{Defensin induced transcriptional factors activation}

A549 epithelial cells were stimulated with defensin (5 and $10 \mu \mathrm{g} /$ $\mathrm{ml}$ ) for desired time as indicated in order to determine the defensin induced the time-course activation of transcriptional factors. AP-1 activation after defensin stimulation occurred as early as $30 \mathrm{~min}$, and reached the maximum at $20 \mathrm{~min}$. There was no significant change in the expression of NF- $\mathrm{kB}$ in defensin-stimulated nuclear extracts (Figure 4).
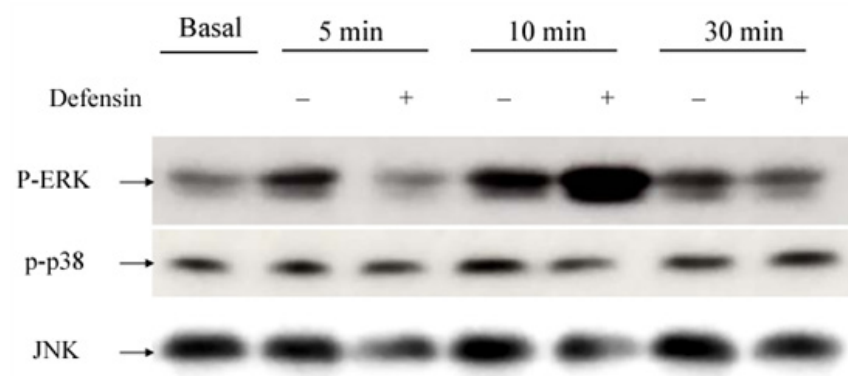

Figure 2 Western blot analysis for the effects of neutrophil defensin (defensin, $10 \mu \mathrm{g} / \mathrm{ml}$ ) on ERKs, p38 MAPK and JNK activities. Neutrophil-defensin increased ERKI/ERK2 activation, and reached the maximum at $10 \mathrm{~min}$, and returned to basal level thereafter.

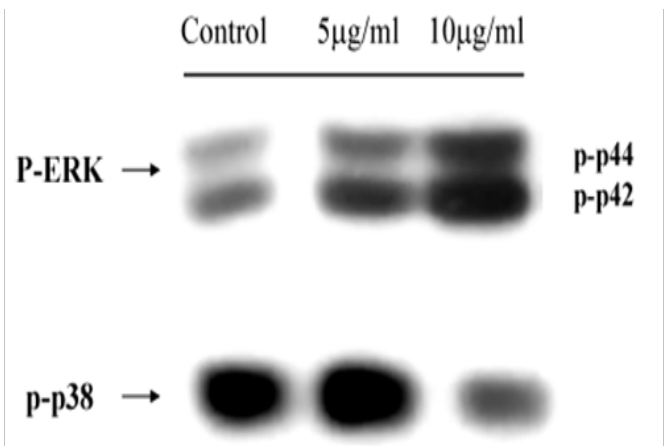

Figure 3 Western blot analysis for the effects of different doses of neutrophil defensin (defensin, $5 \mu \mathrm{g} / \mathrm{ml}$ and $10 \mu \mathrm{g} / \mathrm{ml}$ ) on ERKs and p38 MAPK activities. The ERKI/ERK2 activation occurred after $5 \mathrm{ug} / \mathrm{ml}$ defensin stimulation, and reached the maximum at $10 \mathrm{ug} / \mathrm{ml}$.

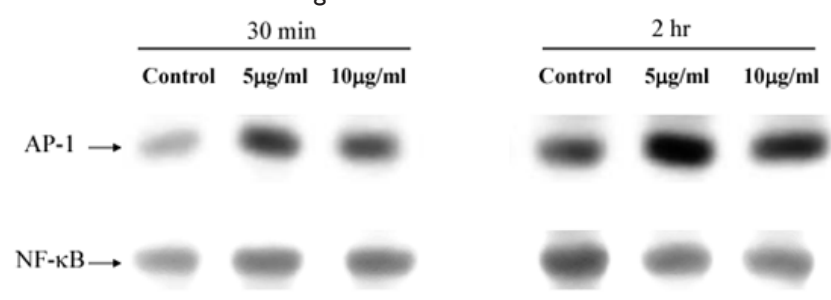

Figure 4 Western blot analysis for the effects of neutrophil defensin (defensin, $5 \mu \mathrm{g} / \mathrm{ml}$ and $10 \mu \mathrm{g} / \mathrm{ml})$ on AP-I and NF- $\kappa$ B activities. AP-I activation after defensin stimulation occurred as early as $30 \mathrm{~min}$, and reached the maximum at $20 \mathrm{~min}$.

\section{Implication of MAKP in defensin ilnduced II-8 protein synthesis}

The ERK inhibitor, PD98059 $(10 \mu \mathrm{g} / \mathrm{ml})$ significantly inhibited defensin $(5$ and $10 \mu \mathrm{g} / \mathrm{ml})$ induced IL-8 release from $390.8+9.5$ to $249.9+9.2 \mathrm{pg} / \mathrm{ml}(\mathrm{n}=5, \mathrm{p}<0.001)$ and from $485.8+12.7$ to $267.5+12.8 \mathrm{pg} /$ $\mathrm{ml}(\mathrm{n}=5, \mathrm{p}<0.001)$ respectively. Pre treatment with a specific $\mathrm{p} 38$ MAPK inhibitor, SB $203580(10 \mu \mathrm{M})$, only inhibited IL-8 release at $5 \mu \mathrm{g} / \mathrm{ml}$ of neutrophil-defensin [from $390.8+9.5$ to $297.1+23.9 \mathrm{pg} /$ $\mathrm{ml}(\mathrm{n}=5, \mathrm{p}<0.01)]$, but did not influence IL-8 production at a higher concentration of defensin $(10 \mu \mathrm{g} / \mathrm{ml})$ (Figure 5).

\section{The involvement of tyrosine kinase and protein kinase C pathway in neutrophil-defensin induced II-8 protein synthesis}

The defensin induced IL-8 release was inhibited by the pre treatment with a tyrosine kinase inhibitor, genistein $(10 \mu \mathrm{g} / \mathrm{ml})$ [from $390.8+9.5$ to $320.6+15.5 \mathrm{pg} / \mathrm{ml}$ (defensin, $5 \mu \mathrm{g} / \mathrm{ml}$, $\mathrm{n}=5$, 
$\mathrm{p}<0.01$ ) and from $485.8+12.7$ to $365.8+14.5 \mathrm{pg} / \mathrm{ml}$ (defensin, $10 \mu \mathrm{g} /$ $\mathrm{ml}, \mathrm{n}=5, \mathrm{p}<0.001)$ respectively] and also by the PKC inhibitor Go $6976(1 \mu \mathrm{M}$, a selective inhibitor of conventional PKC $\alpha, \beta$ and $\gamma)$ [from $390.8+9.5$ to $359.2+9.4 \mathrm{pg} / \mathrm{ml}$ (defensin, $5 \mu \mathrm{g} / \mathrm{ml}, \mathrm{n}=5, \mathrm{p}<0.05$ ) and from $485.8+12.7$ to $314.2+18.5 \mathrm{pg} / \mathrm{ml}$ (defensin, $10 \mu \mathrm{g} / \mathrm{ml}, \mathrm{n}=5$, $\mathrm{p}<0.0001)$ respectively], but not attenuated by the Ro $31-8220(5 \mu \mathrm{M})$ (an inhibitor of all PKC isoforms) (Figure 6). ${ }^{24}$

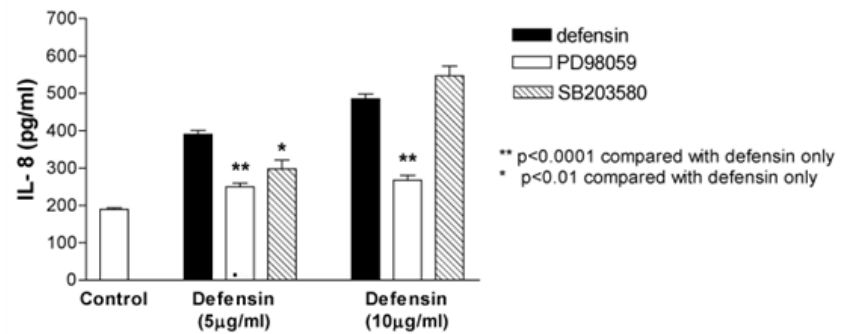

Figure 5 The ERK inhibitor, PD98059 ( $10 \mu \mathrm{g} / \mathrm{ml})$ significantly inhibited defensin $(5$ and $10 \mu \mathrm{g} / \mathrm{ml})$ induced IL-8 release respectively. Pretreatment with a specific p38 MAPK inhibitor, SB $203580(10 \mu \mathrm{M})$, only inhibited IL-8 release at $5 \mu \mathrm{g} /$ $\mathrm{ml}$ of neutrophil-defensin, but did not influence IL-8 production at a higher concentration of defensin $(10 \mu \mathrm{g} / \mathrm{ml})$. $* \mathrm{P}<0.0 \mathrm{l}$ compared with defensin alone; $* * \mathrm{P}<0.000$ I compared with defensin alone. Data are mean+SEM.

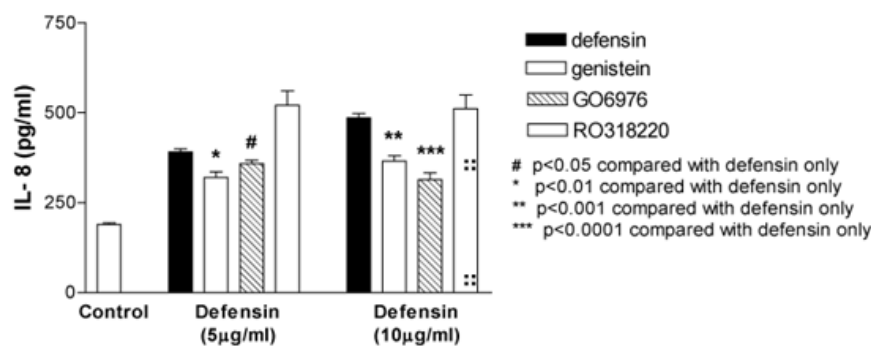

Figure 6 Neutrophil defensin-induced IL-8 release from A549 epithelial cells was inhibited by a tyrosine kinase inhibitor, genistein $(10 \mu \mathrm{g} / \mathrm{ml})$, or a selective inhibitor of conventional PKC $\alpha, \beta$ and $\gamma$, Go 6976 (Go, I $\mu \mathrm{M}$ ), but not the Ro $3 \mathrm{I}-8220(5 \mu \mathrm{M})$. Data are mean+SEM.

Implication of MAKP and tyrosine kinase pathway in defensin induced IL-8 mRNA expression

RT-PCR analysis also showed defensin upregulated IL-8 mRNA expression which was inhibited by PD98059, SB203580, Genistein, and Go 6976 (Figure 7).

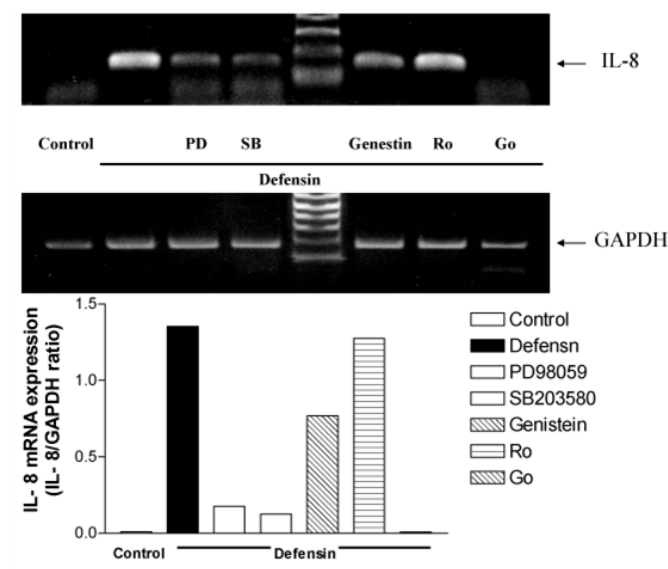

Figure 7 RT/PCR analysis for IL-8 mRNA expression induced by neutrophil defensin in the presence or absence of a tyrosine kinase inhibitor, genistein

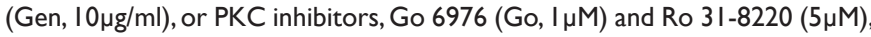
or a specific p38 MAPK inhibitor, SB $203580(\mathrm{SB}, 10 \mu \mathrm{M})$, or the ERK inhibitor, PD98059 (PD, I0 $\mu$ M). GAPDH was used as a housekeeper gene.
Implication of MAKP and tyrosine kinase pathway in defensin induced transcription factors activation

The defensin-induced AP-1 activation was also significantly inhibited by the pre treatment with PD98059, SB203580, PDTC, Genistein, and Go 6976, but not Ro 31-8220. However, neutrophil defensin failed to influence the expression of NF- $\mathrm{\kappa B}$ in the defensinstimulated nuclear extracts (Figure 8).

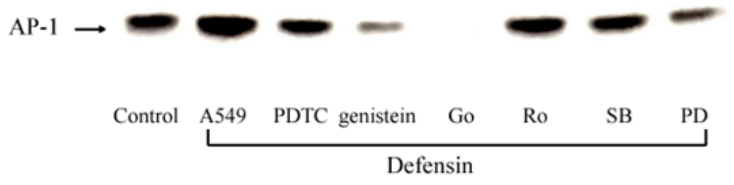

Figure 8 Western blot analysis for the effects of neutrophil defensin (defensin, $10 \mu \mathrm{g} / \mathrm{ml}$ ) on AP-I and NF-B activities, in the presence or absence of a tyrosine kinase inhibitor, genistein $(\mathrm{Gen}, 10 \mu \mathrm{g} / \mathrm{ml})$, or a selective inhibitor of conventional PKC $\alpha, \beta$ and $\gamma$, Go 6976 (Go, I $\mu$ M), or an inhibitor of all PKC isoforms, Ro 3 I-8220 (Ro, 5 $\mu$ M), or a specific p38 MAPK inhibitor, SB 203580 $(\mathrm{SB}, 10 \mu \mathrm{M})$, or the ERK inhibitor, PD98059 (PD, I0 $\mu \mathrm{M})$, or the NF- $\mathrm{KB}$ inhibitor, PDTC $(10 \mu \mathrm{M})$.

\section{The Involvement of tyrosine kinase and protein kinase $C$ pathway in elastase induced MAPK activation}

The defensin induced ERK1/ERK2 activation was inhibited by the pre treatment with PD98059, Genistein, and Go 6976, but not SB203580, PDTC, and Ro 31-8220 (Figure 9).

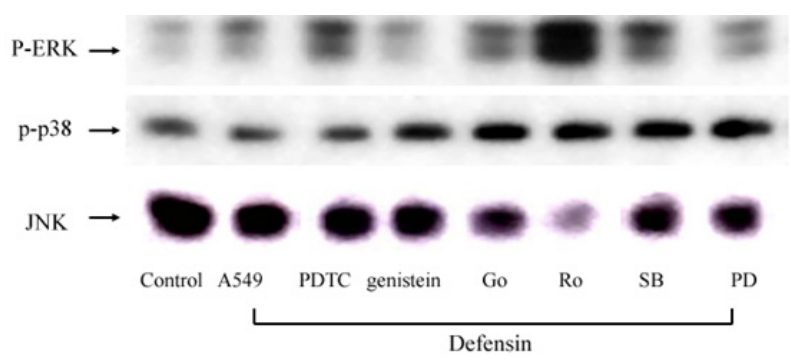

Figure 9 Western blot analysis for the effects of neutrophil defensin (defensin, $10 \mu \mathrm{g} / \mathrm{ml}$ ) on MAPKs activities, in the presence or absence of a tyrosine kinase inhibitor, genistein $(\mathrm{Gen}, 10 \mu \mathrm{g} / \mathrm{ml})$, or a selective inhibitor of conventional PKC $\alpha, \beta$ and $\gamma$, Go 6976 (Go, I $\mu$ M), or an inhibitor of all PKC iso forms, Ro 3I-8220 (Ro, $5 \mu \mathrm{M})$, or a specific P38 MAPK inhibitor, SB 203580 (SB, I $0 \mu \mathrm{M})$, or the ERK inhibitor, PD98059 (PD, I $0 \mu \mathrm{M})$, or the NF- $\kappa B$ inhibitor, PDTC $(10 \mu M)$.

\section{Cytotoxicity and cell detachment}

By TUNEL staining, defensin $(5,10 \mu \mathrm{g} / \mathrm{m})$ significantly increased apoptotic A549 epithelial cells 6hour and 24hour stimulation, compared with the time control and the TUNEL negative control (Figure 10). There was no evident cell detachment within 6hour of defensin $(5$ and $10 \mu \mathrm{g} / \mathrm{ml})$ stimulation when compared to the time control.

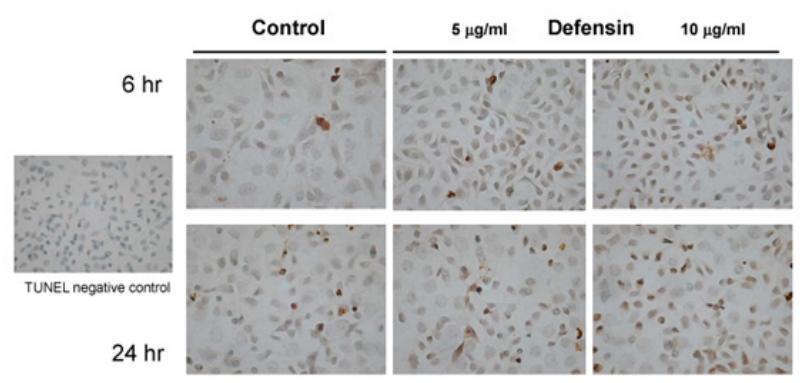

Figure 10 By TUNEL staining, defensin $(5,10 \mu \mathrm{g} / \mathrm{m})$ significantly increased apoptotic A549 epithelial cells 6hour and 24hour stimulation, compared with the time control and the TUNEL negative control. 


\section{Discussion}

In the present study, we have demonstrated that human neutrophil defensin induces IL-8 synthesis and release from A549 epithelial cells. Our study revealed neutrophil defensin induced IL-8 protein production concomitant with IL-8 mRNA up regulated expression, indicating neutrophil defensin directly stimulated IL-8 synthesis. Analysis of the signal transduction pathways regulating IL-8 expression, the activities of MAPK pathways, ERK1/ERK2 and p38 MAPK pathways were examined by western blot analysis. Human neutrophil defensin induced ERK1/ERK2 activation after stimulation. Pre treatment with an ERK inhibitor, PD98059 inhibited IL-8 protein production as well as IL-8 mRNA expression. These results indicate MAPK plays a critical transduction role in IL- 8 expression induced by human neutrophil defensin in A549 epithelial cells. Moreover, human neutrophil defensin also up regulated the activation of transcription factor, AP-1, which was suppressed by MAPK inhibitors.

Previous studies have demonstrated the importance of the MAPK pathway for IL-8 synthesis in human bronchial epithelial cells, ${ }^{25}$ and pulmonary endothelial cells. The need for activation of the MAPK pathway for IL-8 synthesis is not restricted to defensin, since hyper osmolarity, ${ }^{25}$ TNF- $\alpha$ and IL- $1 \alpha^{26}$ induced IL- 8 synthesis are also inhibited by MAPK inhibitors. The ERK1/ERK2 pathway was found also activated by human neutrophil elastase.

The promoter of the gene encoding IL- 8 contains sequences for binding several nuclear transcription factors, including NF- $\kappa \mathrm{B}$ and AP-1. ${ }^{16,17}$ These transcription factors participate to various extents in the inducible expression of the genes encoding IL-8. NF- $\mathrm{KB}$ is a dimeric transcription factor retained in the cytoplasm by its binding

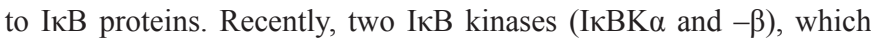
specifically phosphorylated two adjacent serines in I $\mathrm{KB}$ proteins, have been identified. ${ }^{27}$ This phosphorylation results in ubiquitination and

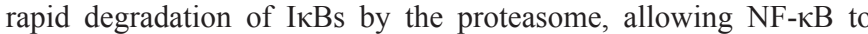
translocate to the nucleus and bind to DNA-regulatory elements within target gene. In contrast to NF-kB site, the AP-1 site was essential for the contribution to IL-8 transcription $^{28,29}$ in some studies. ${ }^{17}$ In the present study, neutrophil defensin induced AP-1 activation, but not $\mathrm{NF}-\kappa \mathrm{B}$. Pretreatment with the NF- $\kappa \mathrm{B}$ specific inhibitor, PDTC, failed to inhibit the defensin-induced IL-8 protein release, suggesting AP-1 was the major transcription factor involved in neutrophil defensin induced IL-8 release from A549 epithelial cells.

The p38 MAPK and ERK kinase have been implicated in the activation of multiple transcription factors, including $\mathrm{AP}-1, \mathrm{NF}-\mathrm{\kappa B}$, CHOP, Elk-1 and ATF-2. ${ }^{8,16,17,30,31}$ In the present study, neutrophil defensin-induced AP-1 activation was significantly abolished by pre treatment with the PD98059, genistein or Go 6976, indicating AP-1 were the implicated downstream transcription factors for defensininduced IL-8 synthesis. The three mitogen-activated protein kinases (MAPK) (ERK1/2, p38, and JNK) have been shown phosphorylated and concomitant with induction of AP-1 DNA binding activity to mediate IL- 8 production. ${ }^{30}$ However, activation of MAPK and AP-1 may be mediated by distinct and separate pathways, mostly through MEKK1-activated pathway. ${ }^{31,32}$ In the present study, the absent activities of JNK pathway, the down-stream of MEKK1 pathway, indicates that activation of AP-1 by ERK $1 / 2$ contributes to a great extent to the neutrophil defensin induced AP-1 activation. Thus, the results show that in human epithelial cells, neutrophil defensin markedly increases, via a MAPK signalling mechanism, AP1 factorassociated responses.
Human neutrophil defensin-induced AP-1 activation was significantly inhibited by a tyrosine kinase inhibitor, genistein and by a selective inhibitor of conventional PKC $\alpha, \beta$ and $\gamma$, Go 6976, indicating AP-1 activation by defensin was the downstream signals of tyrosine kinase. Moreover, genistein also significantly inhibited IL-8 protein synthesis and their mRNA expression. The present study provides evidence that the intracellular signal pathway for human defensin induced IL-8 synthesis by alveolar epithelial cells via AP-1 activation requires the activation of an upstream protein tyrosine kinase. A tyrosine kinase inhibitor, genistein, but not Ro 318220 , significantly attenuated ERK1/2 activation and IL-8 release and mRNA expression, suggesting tyrosine kinase were implicated in these responses. On the other hand, defensin-induced p38 MAPK activation was not attenuated by pre treatment with an inhibitor of PKC $\alpha, \beta$ and $\gamma$ isoforms, Go 6976, indicating p38 MAPK activation pathway was distinct from that of ERK1/2.

In our study, human neutrophil defensin also caused alveolar epithelial cell lysis in the absence of cell detachment. Our observation is in line with previous reports. ${ }^{7,33}$ With respect to defensins and serine proteinases-induced cellular injury and their ability to induce IL-8 synthesis in the lung epithelial cells, defensins induced cell lysis, whereas elastase and cathepsin G induced detachment of A549 cells. Defensins exerted antimicrobial effects in vitro against many Grampositive and Gram-negative bacteria, fungi, mycobacteria and some enveloped viruses, and were cytotoxic to a wide range of normal and malignant targets, including cells resistant to TNF- $\alpha$ and NK-cytolytic factor. Studies with various prokaryotic and eukaryotic cells provided convincing evidence that defensins killed these targets by forming voltage-regulated channels in the susceptible cell's membrane. ${ }^{34}$ Apoptosis, or physiologic cell death, is a process of genetically programmed cell death by which senescent, DNA-damaged, and diseased cells are eliminated from the body. ${ }^{35}$ Little studies were conducted concerning about the association between neutrophil defensin and the apoptosis of human airway epithelial cells. Our data showed that defensin induces apoptosis of A549 alveolar epithelial cells by TUNEL staining method, suggesting defensin mediated IL-8 release may be through an effect on the programmed cell death of epithelial cells. This preliminary result, we believe, is the first report demonstrating the relationship between neutrophil defensin and apoptosis of airway epithelial cells. It needs further investigation and more evidences to confirm.

Based on the data presented in this study, the MAPK pathway and AP-1 are potential therapeutic targets for treatment and prevention of neutrophil-mediated lung injury in which excessive IL-8 production may self-perpetuate leukosequestration in the lungs. Blocking the MAPK pathway and AP-1 activation may be provided by using a specific inhibitor of ERK, such as PD98059 or its upstream tyrosine kinase or PKC by using genistein or Go 6976 .

\section{Acknowledgements}

None.

\section{Conflict of interest}

The author declares no conflict of interest.

\section{References}

1. Sibille Y, Reynolds HY. Macrophages and polymorphonuclear neutrophils in lung defense and injury. Am Rev Respir Dis. 1990;141(2):471-501. 
2. Henson PM, Johnston RB. Tissue injury in inflammation: oxidants, proteinases and cationic proteins. J Clin Invest. 1987;79(3):669-674.

3. Lin HC, Wang CH, Liu CY, et al. Erythromycin inhibits b2-integrins (CD11b/CD18) expression, interleukin-8 release and intracellular oxidative metabolism in neutrophils. Respir Med. 2000;94(7):654-660.

4. Kwon OJ, Au BT, Collins PD, et al. Tumor necrosis factor-induced interleukin 8 expression in cultured human airway epithelial cells. $\mathrm{Am} J$ Physiol. 1994;267(4 Pt 1):L398-L405.

5. Khair OA, Davies RJ, Devalia JL. Bacteria-induced release of inflammatory mediators by bronchial epithelial cells. Eur Respir J. 19996;9(9):1913-1922.

6. Carolan EJ, Casale TB. Neutrophil transepithelial migration is dependent upon epithelial characteristics. Am J Respir Cell Mol Biol. 1996;15(2):224-231.

7. Van Wetering S, Mannesse-Lazeroms SP, Dijkman JH, et al. Effect of neutrophil serine proteinases and defensins of lung epithelial cells:modulation of cytotocity and IL-8 production. J Leukoc Biol. 1997;62(2):217-226

8. Davis RJ. MAPKs: new JNK expand the group. Trends Biochem Sci. 1994;19(11):470-473.

9. Beyaert R, Cuenda A, Vanden Berghe W, et al. The p38/JNK mitogenactiavted protein kinase pathway regulates interleukin-6 synthesis in response to tumor necrosis factor. EMBO J. 1996;15(8):1914-1923.

10. Raingeaud J, Gupta S, Rogers JS, et al. Pro-inflammatory cytokines and environmental stress cause p38 mitogen-activated protein kinase activation by dual phosphorylation on tyrosine and threonine. $J$ Biol Chem. 1995;270(13):7420-7426

11. Foltz IN, Lee JC, Young PR, et al. Hemopietic growth factors with the exception of interleukin-4 activate the p38 mitogen-activated protein kinase pathway. J Biol Chem. 1997;272(6):3296-3301.

12. Matsumoto K, Hashimoto S, Gon Y, et al. Proinflammatory cytokineinduced and chemical mediator-induced IL-8 expression in human bronchial epithelial cells through p38 mitogen-activated protein kinasedependent pathway. J Allergy Clin Immunol. 1998;101(6 Pt 1):825-831.

13. Manthey CL, Wang SW, Kinney SD, et al. SB202190, a selective inhibitor of p38 mitogen-activated protein kinase, is a powerful regulator of LPSinduced mRNAs in monocytes. J Leukoc Biol. 1998;64(3):409-417.

14. Hobbie S, Chen LM, Davis RJ, et al. Involvement of mitogen-activated protein kinase pathways in the nuclear responses and cytokine production induced by Salmonella typhimurium in cultured intestinal epithelial cells. J Immunol. 1997;159(11):5550-5559.

15. Carter AB, Monick MM, Hunninghake GW. Both Erk and p38 kinases are necessary for cytokine gene trascription. Am J Respir Cell Mol Biol. 1999;20(4):751-758

16. Baeuerle PA, Henkel T. Function and activation of NF-kB in the immune system. Annu Rev Immunol. 1994;12:141-179.

17. Mastronarde JG, Monick MM, Mukaida N, et al. Activator protein-1 is the preferred transcription factor for cooperative interaction with nuclear factor-kappaB in respiratory syncytial virus-induced interleukin- 8 gene expression in airway epithelium. J Infect Dis. 1998;177(5):1275-1281.

18. Wang XZ, Ron D. Stress-induced phosphorylation and activation of the transcription factor CHOP (GADD153) by p38 MAP Kinase. Science. 1996;272(5266):1347-1349.
19. Wesselborg S, Bauer MK, Vogt M, et al. Activation of transcription factor NF-kappaB and p38 mitogen-activated protein kinase is mediated by distinct and separate stress effector pathways. J Biol Chem. 1997;272(19):12422-12429.

20. Kuo HP, Lin HC, Huang KS, et al. Lipopolysaccharide enhances substance $\mathrm{P}$-induced neutrophil adherence and related cytokine release Am J Respir Crit Care Med. 2000;162(5):1891-1897.

21. Lin HC, Wang $\mathrm{CH}$, Yu CT, et al. Endogenous nitric oxide inhibits neutrophil adherence to lung epithelial cells to modulate interleukin-8 release. Life Sci. 2001;69(11):1333-1344.

22. Martiny-Baron G, Kazanietz MG, Mischak H, et al. Selective inhibition of protein kinase $\mathrm{C}$ isozymes by the indolocarbazole Go 6976. J Biol Chem. 1993;268(13):9194-9197.

23. Chen CC, Wang JK. p38 but not p44/42 mitogen-activated protein kinase is required for nitric oxide synthase induction mediated by lipopolysaccharide in RAW 264.7 macrophages. Mol Pharmacol. 1999;55(3):481-488.

24. Chomezynski P, Sacchi N. Single-step method of RNA isolation by acid guanidinium thiocyanate-phenol-chloroform extraction. Anal Biochem. 1987;162(1):156-159.

25. Hashimoto S, Matsumoto K, Gon Y, et al. Hyperosmolarity-induced interleukin-8 expression in human bronchial epithelial cells through p38 mitogen-activated protein kinase. Am J Respir Crit Care Med. 1999;159(2):634-640.

26. Hashimoto S, Matsumoto K, Gon Y, et al. p38 mitogen-activated protein kinase regulates IL-8 expression in human pulmonary vascular endothelial cells. Eur Respir J. 1999;13(6):1357-1364.

27. Woronicz JD, Gao X, Cao Z, et al. IkB kinases-b: NF-kB activation and complex formation with $\mathrm{IkB}$ kinase-a and NIK. Science. 1997;278(5339):866-869.

28. Mukaida N, Okamoto S, Ishikawa Y, et al. Molecular mechanisms of interleukin-8 gene expression. J Leukoc Biol. 1994;56(5):554-558.

29. Harant H, de Martin R, Andrew PJ, et al. Synergistic activation of interleukin- 8 gene transcription by all-trans-retinoic acid and tumor necrosis factor-a involves the transcription factor NF-kB. J Biol Chem. 1996;271(43):26954-26961.

30. Dahan S, Busuttil V, Imbert V, Peyron JF, et al. Enterohemorrhagic Escherichia coli infection induces interleukin-8 production via activation of mitogen-activated protein kinases and the transcription factors NFkappaB and AP-1 in T84 cells. Infect Immun. 2002;70(5):2304-2310.

31. Balasubramanian S, Efimova T, Eckert RL. Green tea polyphenol stimulates a Ras, MEKK1, MEK3, and p38 cascade to increase activator protein 1 factor-dependent involucrin gene expression in normal human keratinocytes. J Biol Chem. 2002;277(3):1828-1836.

32. Raingeaud J, Whitmarsh AJ, Barrett T, et al. MKK3-and MKK6-regulated gene expression is mediated by the $\mathrm{p} 38$ mitogen-activated protein kinase signal transduction pathway. Mol Cell Biol. 1996;16(3):1247-1255.

33. Shibata $\mathrm{Y}$, Nakamura $\mathrm{H}$, Kato $\mathrm{S}$, et al. Cellular detachment and deformation induce IL-8 gene expression in human bronchial epithelial cells. J Immunol. 1996;156(2):772-777.

34. Kagan BL, Ganz T, Lehrer RI. Defensins: a family of antimicrobial and cytotoxic peptides. Toxicology. 1994;87(1-3):131-149.

35. Sookhai S, Wang JJ, McCourt M, et al. A novel therapeutic strategy for attenuating neutrophil-mediated lung injury in vivo. Ann Surg. 2002;235(2):285-291. 